\title{
An Analysis on the Effectiveness of Team Building: The Impact on Human Resources
}

\author{
Wan Idros Wan Sulaiman (Corresponding author) \\ School of Media and Communication Studies \\ National University of Malaysia, Bangi UKM 43600, Selangor, Malaysia \\ Tel: 60-3-8921-3588_E-mail:wiws@ukm.my \\ Maizatul Haizan Mahbob \\ School of Media and Communication Studies \\ National University of Malaysia, Bangi UKM 43600, Selangor, Malaysia \\ Tel: 60-3-8921-5464 E-mail:maiz@ukm.my \\ Badrul Redzuan Abu Hassan \\ School of Media and Communication Studies \\ National University of Malaysia, Bangi UKM 43600, Selangor, Malaysia \\ Tel: 60-3-8921-5811 E-mail: badrulrah@gmail.com
}

$\begin{array}{lc}\text { Received: February 21, } 2012 & \text { Accepted: March 13, } 2012 \quad \text { Published: April 16, } 2012 \\ \text { doi:10.5539/ass.v8n5p29 } & \text { URL: http://dx.doi.org/10.5539/ass.v8n5p29 }\end{array}$

The research is financed by PEMACU Research Grant Code: GPP-2011-003

\begin{abstract}
The scope of discussion in this study includes the aspect of human resource management and administration that focuses on the effectiveness of team building in producing employees who are skilled, innovative, creative, competitive and alert to the needs of the organization. In this context, we evaluate and analyze the effectiveness of the function of human resource team building by looking at three key factors: Task Oriented Roles Factor, Relationship Oriented Roles Factor and Self Oriented Roles Factor. In this descriptive study, about 150 ancillary staffs at the National University of Malaysia have been randomly identified as the respondents. This study attempts to analyse the extent in which the effective function of team building may be factored upon the sheer spirit, job motivation and high-level skill of these employees which may indirectly reflect the status and strength of the aspect of human resource management. The data of this study are analysed using the Statistical Package for Social Sciences (SPSS) program (version 17.0 for Windows). It is hoped that the publication of this study will contribute ideas and opinions towards improving and consolidating the function of human resource development that is in line with the mission and vision of the university as well as the government in general, in creating skilled and effective civil servants.
\end{abstract}

Keywords: Effectiveness, Team building, Human resource, Organizational leadership, Work force

\section{Introduction}

The style of management and administration of an efficient organization usually stems from a competent and effective management system; whereas a competent system derives from an effective organizational leadership. There are undoubtedly many factors attributed to the fact above and one of the key contributing factors towards a competent management and administration style is team building. Team building is an important catalyst in the organizational relations between organizations; in fact, it is the main stimulus/vehicle in fostering closer ties between the top and bottom management teams or in other words, between the employers and their employees. 
Oftentimes, a close employer-employee relationship will be influential in determining the management style of the employees in that organization. Besides this, team building is also believed to be capable in reinforcing the skills of the workforce in three main areas namely, attitude, skills and knowledge (ASK).

It is never an easy thing to 'create' a capacity for personalia relationship in an organization. Employers need to strengthen their own repertoire of skills/expertise, for instance, the capacity to relate and interact with their subordinates; to 'read'/ analyze the needs of their staff; to win their hearts with a leadership style that is appropriate and adequate in order to cater for the current context, demands and issues in human resource management. Besides that, employers also have to be prepared and 'alert' to deal with any form of change. Meaning to say, whatever the change is, whether in terms of technology, thinking, relationship, labour demands or external competition to name a few, it will have to be negotiated with insight and discretion. But the persistent question on the extent of the effectiveness of the style of team building practice within an organization remains because it is dependent upon the individual managing that organization. This study is carried out to analyze and identify the effectiveness of team building in the context of the management and administration of a university. This study, which involves the support staff of the National University of Malaysia (UKM), will focus on their views towards the effectiveness of the roles and contribution of team building as a practice within the civil service.

\section{Statement of Problem}

There are so many issues connected to the organizational problems of human resource management that can be gleaned from scholarships and observations. Thus, we are 'exposed' to the sharp criticism which allegedly claim that government servants are apathetic, unfriendly, non-competitive, tend to keep important information on his/her organization to his/herself, demotivated, resistant to change, uncooperative and lacking in regular supervision and good leadership compared to that of the private sector (Hasmuny Osmat, 1993). Such scenario has a huge negative impact (even perceived as a form of pressure on the government) on the civil service since it is mostly concerned with the problems of human resource. Therefore, what is the role and contribution of team building in this matter?

This study also intends to analyze and discuss the extent to which the role and contribution of team building in an organization can enhance the competency of organizational management (in the context of job effectiveness, attitude, skills and human resource development in the organization). The question here is, whether the elements of leadership for an effective team building that are dependent on factors (like organizational culture and policy, working environment and professional activities, managerial/management values and experience) should not be seen as justifiable in determining the effectiveness of the task and responsibility(Wan Idros Wan Sulaiman, 1999). Or whether humanitarian factors such as style, methodology and the pattern of interaction, training and development programs, professional attitude and reward have not been given the full attention by the top-level management (Greenberg \& Baron, 1997) Is it possible that because of the rapid changes and improper implementation of organizational duties, employees have fallen under a huge pressure which further sustains the concept of work-related stress? Thus, to what extent is the contribution of organizational management significant in constructing or building organizational force/team? These are the questions that motivate us to explore and analyze the extent of the role of team building at the workplace is being enforced and practiced by the top management to ensure that their employees' organizational skills and expertise can be improved. In this study, our focus is to examine holistically the extent of the effectiveness of three key role oriented factors pertaining to team building, namely (i) Task Oriented Roles Factor, (ii) Relationship Oriented Roles Factor and (iii) Self Oriented Roles Factor.

\section{Research Methodology}

This is a descriptive study that focuses on the opinion survey of respondents from among the support staff of UKM. For the purposes of gathering data and accurate information, we deploy questionnaires comprising two sections, A and B. Section A details the respondents' background whereas Section B focuses on three important aspects: (i) Task Oriented Roles Factor, (ii) Relationship Oriented Roles Factor and (iii) Self Oriented Roles Factor. About 150 set of questionnaires are distributed to 150 respondents. The questionnaires are distributed through a range of techniques such as self-administered technique and individual technique (Babbie, 2001).

We have chosen questionnaire as the research instrument due to its inherently accurate and cost-saving factors. We believe that a questionnaire that has been accurately and appropriately developed will provide the studied respondents the ease and understanding when responding besides saving its time and cost too. All information and data will be analyzed using the Statistical Package for Social Sciences (SPSS) (version 17.0) software. 


\section{Research Conceptual Framework}

In order to facilitate this study, we summarize the content of this study in the form of a conceptual framework shown below:

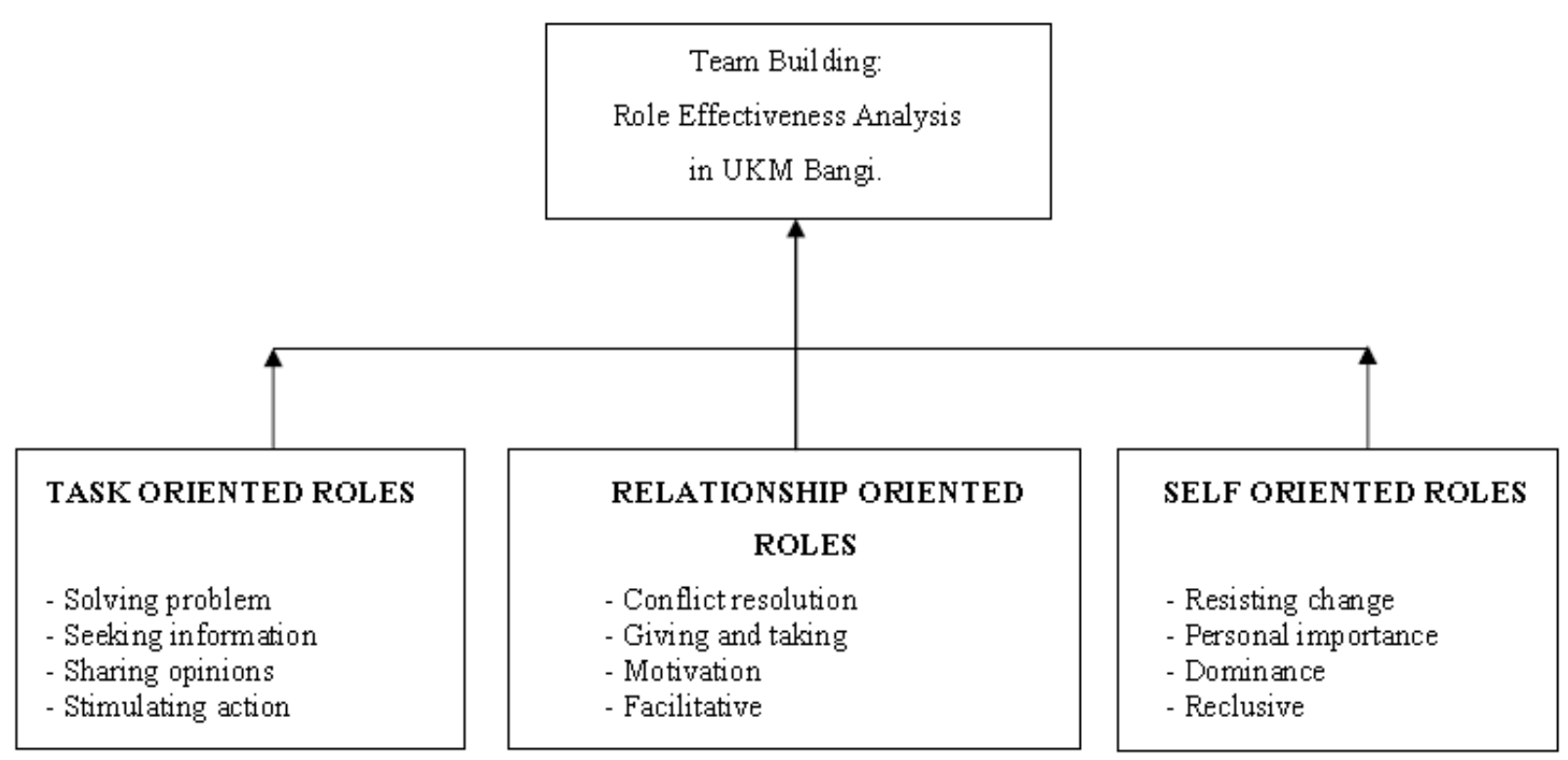

\section{Review of Literature}

Group communication in an organization is frequently seen as one of the catalysts in shaping and consolidating its organizational administration and management system. In this regard, Ab. Aziz Yusof (2003) believes that the purposes of communication in a group work or an organization are mainly in regulating/control, motivating, expressing feelings and conveying information. An excellent manager is one who is able to communicate to his/her subordinates and higher management the direction and position of his/her organization either in the short or long term. Given their superior communication skills, they should be capable to identify and recognize the potentials of their subordinate (Ab. Aziz Yusof, 2003). Actually much of this owes to the capability of upper-tier managers to perceive the attitude, emotion and habits of their subordinates and in fact, this capacity is critical in order to win the allegience of the employees to the organization (Kramer \& Hess, 2002). Torrington, Hall and Taylor (2002) have argued that in order to improve the image of the organization, it must set its human resources asset as the first priority. Positive values of an efficient organizational communication should become the practice and culture of excellence within the organization because they also can boost the quality of the work force in general.

Communication plays a very important function in the dissemination of information and day-to-day operation of any organization (whether it is big or small). Any organizational management style requires communicative function in order to improve a broad range of expertise such as technical skills, human skills, conceptual and planning skills. Task based skills, for example, cannot be achieved if the superior management does not have the capacity to provide the relevant information and establish a nexus of relationship between the three skills above. Technical skills are important at the supervisorial level, whereas human skills in the interactive process between a leader and his/her support staff and vice versa. For high-level management, conceptual skills and the intellectual maturity showed in charting organizational vision and mission obviously are very important (Rosli Mohammed, 2001). On the basis of this 'creed', employers should be taking the sensible and necessary measures to identify the enabling factors to induce the acquisition of the skills mentioned. Nevertheless, according to Byers (1997), in the effort both to improve the expertise of employees and organizational image, all employers must always try to understand and be fully aware of the actual capability of each individual character in their organizations. But if this factor is neglected, an organization stands the risk of inducing the problem of 'resistance towards change' among its workers.

Blundel (2004) believes that most conflicts and crises that happen inside an organization are practically caused by the lack of transparent communication among members of the organization. He stresses that the superior management team should look into the importance of organizational communication from various encompassing dimensions including psychological and neurological, social, cultural and ethical concerns of every staff under 
their supervision and this is even more critical for the organization's team building process. Hence, this can reduce a lot of the tension straining the relationship between employer and their employee.

In this case, we do not deny that the civil sector have exposed that many organizational crises are extant among working groups, for example, internal group conflict, bureaucratic antics, the casual attitude of both employer and employee when carrying out their duties, the less than conducive working environment, poor customer services, resistance towards change, reclusiveness and office politics. Apparently, Wells and Spinks (1999) in their article 'Communicating with the community', too acknowledge that these crises will keep recurring in civil organizations. This situation above is a reflection of an organization's environment. As pointed out by Miller (1999), it is necessary that the entire workforce, especially the superior management team, be made management and administration system that succumbs to failure. Therefore, employer and employee need to 'work out' something in order to change unhealthy work ethos and culture inside the organization's to understand the concept and practice of organizational communication in two distinct forms, the content of communication and the direction in which the task should be carried out by each individual so that the target and objectives may be accomplished without any critical human resource problem.

It follows that the civil sector should be given encouragement to try out various programs and activities that can promote improvement in effective communication style so that the administrative and management system can also be enhanced. Muhammad Rais Karim (1998) has clearly stated for any civil organization to move forward and in line with the long term vision and mission of the government, a positive work ethos (we believe that positive work ethics and norms should also be emphasized) and self-appreciation amongst civil sector employees is a significant means to implementing and strengthening the Quality Improvement Team (QIT). The consolidation of QIT should be seen as the primary catalyst across government agencies for it can promote better relationship among civil servants as much as it is also capable of improving the productivity and quality of service of civil sector employees, albeit indirectly. He also suggests that government agencies should initiate a mindset reform agenda by wholly endorsing for a quality enculturation-oriented campaign inside their organizations in order to consolidate the structure and practice of the civil sector. In this context, Cole and Scott (2000) show greater preference for the work team concept as a way of managing change in the organization. They have emphasized three key aspects which should be given attention to, that is, motivation, education/training and change, which they believe will be able to enhance the skills and positive attitude of the employees as they strive to fulfill each other's roles and responsibilities.

\section{Discussion of Findings}

This study involves 150 respondents comprising non-academic support staff in UKM. Out of 150 respondents, $71(47.3 \%)$ are male employees compared to $79(52.7 \%)$ female employees. Findings of the study in Table 1 have shown that majority respondents or $52 \%$ have more than 20 years of working experience with the STPM/HSCE as their highest level of education qualification.

From the aspect of Task Oriented Roles Factor, the findings of the study revealed that almost all respondents reacted positively to the idea that team building is a catalyst for the resurgence of the spirit of professionalism as much as for the intellectual benefit in the exchange of ideas and information amongst themselves. Apart from that, they also thought that the team building practice can create and cater for the process of sharing of ideas including the generation of positive action and behavior among employees.

Finally, all respondents agreed that having a team work can instill good values and awareness in them and towards their jobs. Overall, Table 2 findings discovered that almost all respondents thought that team building have given them very clear understanding about their responsibilities. Therefore, Task Oriented Roles proves to be invaluable for an effective team building exercise in dealing with human resource issues in UKM in the context of organizational management and administration.

Table 3 illustrates that UKM's support staff are capable of successful conflict resolution through collaborative means although they believed and perceived that conflicts do regularly happen amongst them. We think that this may have been caused by the job stress faced by them in their respective offices. Although they are in the same category, their work load and duties may differ, depending on where they work. It has become a prevalent condition in UKM whereby certain departments or schools may find themselves on a heavier work load which oftentimes is a result of their own 'hyperactivity' such as organizing seminars, colloquia, students activities and many more.

Nevertheless, the respondents thought that they can learn through team building to give and take which can directly foster and improve the harmonious relationship between them. They also did not deny that they have 
always been encouraged to participate and express their opinions and feelings about their career. This can reduce the confusion of the employees about their work and the roles that they have to assume. The findings also found that work team leaders are always driving forward and motivating his or her team members when given tasks.

The findings also learnt that team mates or peers frequently acknowledge each other every time they properly completed their task with the complimentary 'thank you's'. Overall, the findings discovered that almost all respondents thought that team building is a catalyst in increasing the awareness about the importance of having good relationship in discharging their organizational responsibilities. Indirectly, this answers the second objective of this study that is to examine the Relationship Oriented Roles for team building exercise in dealing with human resource issues in UKM in the context of the effectiveness of human resource management.

The findings in Table 4 show that every team building is always guided by positive team culture which is due to the high commitment from work team members in discharging their duties and responsibilities. The majority of respondents thought that every team member is skilled and always prepared to share resources, products and rewards with their team mates and most of them thought that the extant of team building at their workplace will indirectly developed their own leadership qualities.

The findings revealed that every team member is given equal portion of responsibility. The respondents denied the suggestion that team building were not based on organizational process or procedure. The study also found that employers do run self evaluation on their employees after the completion of team building task and after the set aims have been achieved. Finally, study also indicates that almost all respondents agreed that team building has helped in moulding their individual characteristics into positives which ensures that they will be performing their organizational roles to the best of their ability. Indirectly, this also answers the question on Self Oriented Roles by confirming that behaviours such as resistance to change, ensuring self importance and reclusivity are not the practice and culture of UKM's support staff.

\section{Correlation}

\subsection{Analysis - Research Findings}

Besides the analysis of the findings, we also use correlation analysis in order to seek accuracy in determining the relationship between all three factors of team building. We have summarized each factor statement as shown in the tables below:

i) Task Oriented Roles Factor $=$ Factor 1

ii) Relationship Oriented Roles Factor $=$ Factor 2

iii) Self Oriented Roles Factor $=$ Factor 3

In this study, the correlation analysis involves the following:

i) Relationship Analysis between Factor 1 and Factor 2 (Table 5)

ii) Relationship Analysis between Factor 1 and Factor 3 (Table 6)

iii) Relationship Analysis between Factor 2 and Factor 3 (Table 7) (Note1)

\subsection{Overall conclusion on the result of correlation analysis}

The overall findings of this study indicate that a positive significant relationship is prevalent in all three aspects of team building. The difference is in the potency of the correlations across these aspects. This demonstrates that all three aspects (i) Task Oriented Roles Factor (ii) Relationship Oriented Roles Factor and (iii) Self Oriented Roles Factor are the main elements that must be factored measuring the effectiveness and the strength in any team building effort.

\section{Conclusion and Significance of Study}

The research findings in this study have demonstrated two significant points with regard to effective team building. First, it shows that team building should be enforced entirely in UKM so that it can be incorporated as one of the compulsory norms and values of the institution's corporate culture. Second, it reveals that the elements of soft skills such as communication skills, the ability to handle crisis and problem in the work place, the traits of information sharing and motivation amongst workers should be monitored.

We hope that this study will contribute some ideas for the university administrators so that they may be more transparent and practical in studying the types and effects of team building in all UKM faculties. This study is 
expected to enlighten the administrators further on the roles and significant function of team building in strengthening the university's human resource management system. We also aspire that the findings of this study will yield a positive impact (such as quality of service, understanding job description, leadership style and the organizational culture) on the administrators and their staff in general in their effort to build a more transparent organization that which can overcome the massive issues of bureaucracy in their services.

\section{References}

Ab. Aziz Yusof. (2003). Gelagat organisasi: Teori, isu dan aplikasi $\left(1^{\text {st }}\right.$ ed.). Kuala Lumpur: Prentice Hall/Pearson Malaysia Sdn Bhd.

Ab. Aziz Yusof. (2003). Komunikasi untuk pengurus. Kuala Lumpur: Utusan Publications \& Distributors Sdn Bhd.

Babbie, E. (2001). The practice of social research. Belmont, CA: Wadsworth Thompson Learning.

Blundel, R. (2004). Effective organizational communication: Perspectives, principles and practices ( $2^{\text {nd }}$ ed.). Harlow: FT Prentice Hall.

Byers, P. H. (1997). Organizational communication: Theory and behavior. Boston: Allyn and Bacon.

Cole, E. R. \& Scott, W. R. (2000). The quality movement and organization theory. London: Sage Publications.

Fowler, Jr., F. J. (1988). Survey research methods. Newbury Park, CA: Sage Publications Inc.

Guilford, J. P. (1956). Fundamental statistics in psychology and education. New York: McGraw-Hill.

Hasmuny Osmat. (1993). Hubungan antara faktor galakan dan motivasi kerja: perbandingan antara sektor awam dan sektor swasta dalam motivasi kerja dan persepsi terhadap faktor galakan. Academic Exercise, UKM.

Kramer, M. W. \& Hess, J. A. (2002). Communication rules for the display of the emotions in organizational setting. Management Communication Quarterly, 14(1): 50-89.

Miller, K. (1999). Organizational communication: Approaches and processes. Belmont, CA: Wadsworth Publishing Company.

Mohd Majid Konting. (2004). Kaedah penyelidikan pendidikan. Kuala Lumpur: Dewan Bahasa dan Pustaka.

Muhammad Rais Karim. (1998). Cabaran pembaharuan pentadbiran sektor awam menjelang abad ke 21. Paper presented at the National Seminar on the Renewal of the Malaysian Civil Service. UKM.

Rosli Mohammed. (2001). Amalan komunikasi dalam pengurusan organisasi. In Mohd Baharudin Othman dan Mohd Taib Ariffin (eds.), Komunikasi kepengurusan. Sintok: UUM.

Skeatsley, P. B. (1983). Questionnaire construction and item writing. In Rossi, P. H., Wright, J. D. \& Anderson, A. B. (eds.), Handbook of survey research. Orlando: Academic Press Inc.

Torrington, D., Hall, L. \& Taylor, S. (2002). Human resources management (5 $5^{\text {th }}$ ed.). Harlow: FT Prentice Hall.

Wan Idros Wan Sulaiman. (1999). Teori kepimpinan karismatik. In Ghazali Mayudin. (ed.), Teori sains politik pilihan: Aplikasinya dalam konteks Malaysia. Bangi: Penerbit UKM.

Wells, B. \& Spinks, N. (1999). Communicating with the community. Career Development International, 4(2): 108-116. http://dx.doi.org/10.1108/13620439910254759

\section{Note}

Note 1. All results in this study are based on Guilford's Rule of Thumbs. 
Table 1. Background of respondents

\begin{tabular}{|l|cc|}
\hline \multicolumn{3}{|c|}{ 1. } \\
\hline Male & 71 & $(47.3 \%)$ \\
\hline Female & 79 & $(52.7 \%)$ \\
\hline Total & 150 & $(100 \%)$ \\
\hline
\end{tabular}

\section{Duration of Employment}

\begin{tabular}{|l|cr|}
\hline a) $1-5$ years & 8 & $(5.4 \%)$ \\
\hline b) 6-10 years & 8 & $(5.4 \%)$ \\
\hline c) 11-15 years & 10 & $(6.6 \%)$ \\
\hline d) 16-20 years & 46 & $(30.6 \%)$ \\
\hline e) more than 20 years & 78 & $(52 \%)$ \\
\hline
\end{tabular}

3. Level of Education

\begin{tabular}{|l|cr|}
\hline a) SRP/LCE & 5 & $(3.4 \%)$ \\
\hline b) SPM/MCE & 25 & $(16.6 \%)$ \\
\hline c) STPM/HSCE & 120 & $(80 \%)$ \\
\hline
\end{tabular}

Table 2. Responsibility oriented roles factor

\begin{tabular}{|c|c|c|c|c|c|c|c|}
\hline No. & \multicolumn{6}{|c|}{ TEST ITEMS } & MEAN \\
\hline 1 & \multicolumn{6}{|c|}{ The main function of team building is to solve problems at the work place } & 3.7 \\
\hline 2 & \multicolumn{6}{|c|}{ Team building brings about more problems than solutions } & 1.3 \\
\hline 3 & \multicolumn{6}{|c|}{ Team building stimulates my thought to seek solutions to my work related problems } & 3.7 \\
\hline 4 & \multicolumn{6}{|c|}{ More work related information can be gained by becoming a team member } & 3.8 \\
\hline 5 & \multicolumn{6}{|c|}{ The process of seeking information is easier when other people are not involved } & 2.3 \\
\hline 6 & \multicolumn{6}{|c|}{ I do not have the habit of seeking for information at work } & 1.5 \\
\hline 7 & \multicolumn{6}{|c|}{ I share my true opinions in my work team } & 3.6 \\
\hline 8 & \multicolumn{6}{|c|}{ We hardly exchange our ideas at work because everyone is always busy } & 1.3 \\
\hline 9 & \multicolumn{6}{|c|}{ Exchanging opinions with each other in the organization is a good thing } & 3.8 \\
\hline 10 & \multicolumn{6}{|c|}{ A work team can generate positive action and behavior in the organization } & 3.8 \\
\hline 11 & \multicolumn{6}{|c|}{ I am active member of my work team in the organization } & 3.6 \\
\hline \multirow[t]{4}{*}{12} & \multicolumn{6}{|c|}{ Team building can promote good values and awareness about my work and responsibilities } & 4.0 \\
\hline & \multicolumn{6}{|c|}{ Indicators } & \\
\hline & 1 & Strongly Disagree & 3 & Not Sure & 5 & Strongly Agree & \\
\hline & 2 & Disagree & 4 & Agree & & & \\
\hline
\end{tabular}


Table 3. Relationship oriented roles factor

\begin{tabular}{|c|c|c|c|c|c|c|c|}
\hline No. & \multicolumn{6}{|c|}{ TEST ITEMS } & MEAN \\
\hline 13 & \multicolumn{6}{|c|}{ Most problems and conflicts are resolved together } & 3.2 \\
\hline 14 & \multicolumn{6}{|c|}{ Conflict in a work team happens regularly in an organization } & 3.5 \\
\hline 15 & \multicolumn{6}{|c|}{$\begin{array}{l}\text { I do not believe that every issue or problem can increase good values and awareness about my } \\
\text { work and responsibilities }\end{array}$} & 3.8 \\
\hline 16 & \multicolumn{6}{|c|}{ I always give and take at the work place } & 3.9 \\
\hline 17 & \multicolumn{6}{|c|}{ Team building in an organization helps to improve harmony and tolerance } & 3.1 \\
\hline 18 & \multicolumn{6}{|c|}{ Being over-tolerant makes me feel hypocritical towards my work and responsibilities } & 3.3 \\
\hline 19 & \multicolumn{6}{|c|}{ I am always encouraged to give my opinion on team building } & 3.7 \\
\hline 20 & \multicolumn{6}{|c|}{ I am not allowed to help each other } & 1.0 \\
\hline 21 & \multicolumn{6}{|c|}{ I am often confused when I am doing my work and duties } & 1.3 \\
\hline 22 & \multicolumn{6}{|c|}{ My team leader is not motivated } & 1.3 \\
\hline 23 & \multicolumn{6}{|c|}{ I often argue with my colleagues } & 1.0 \\
\hline \multirow[t]{4}{*}{24} & \multicolumn{6}{|c|}{ My team mates often thank me after the completion of every task } & 3.6 \\
\hline & \multicolumn{6}{|c|}{ Indicators } & \\
\hline & 1 & Strongly Disagree & 3 & Not Sure & 5 & Strongly Agree & \\
\hline & 2 & Disagree & 4 & Agree & & & \\
\hline
\end{tabular}

Table 4. Self oriented roles factor

\begin{tabular}{|c|c|c|c|c|c|c|c|}
\hline No. & \multicolumn{6}{|c|}{ TEST ITEMS } & MEAN \\
\hline 25 & \multicolumn{6}{|c|}{ The work team does not practice team work culture because everyone is selfish } & 1.1 \\
\hline 26 & \multicolumn{6}{|c|}{ The team work commitment is not high when performing its task and responsibilities } & 1.0 \\
\hline 27 & \multicolumn{6}{|c|}{ Members in a work team are unskilled and misfits } & 1.0 \\
\hline 28 & \multicolumn{6}{|c|}{ The work team always share its resources, products and rewards after completing the task } & 3.7 \\
\hline 29 & \multicolumn{6}{|c|}{ Members are not fully focused on their scope of work when performing their task } & 2.3 \\
\hline 30 & \multicolumn{6}{|c|}{ Hierarchical level is limiting work team from performing its task } & 2.8 \\
\hline 31 & \multicolumn{6}{|c|}{ Information received is not disseminated to team members } & 1.2 \\
\hline 32 & \multicolumn{6}{|c|}{ Team building helps members foster their leadership qualities } & 3.9 \\
\hline 33 & \multicolumn{6}{|c|}{ There is no supervision on members performing their task during team building } & 1.3 \\
\hline 34 & \multicolumn{6}{|c|}{ Members are not given extra work load } & 3.0 \\
\hline 35 & \multicolumn{6}{|c|}{ Team building is based on the process and procedure of the organization } & 3.8 \\
\hline \multirow[t]{4}{*}{36} & \multicolumn{6}{|c|}{ Self evaluation is performed after team building achieves its objectives } & 3.5 \\
\hline & \multicolumn{6}{|c|}{ Indicators } & \\
\hline & 1 & Strongly Disagree & 3 & Not Sure & 5 & Strongly Agree & \\
\hline & 2 & Disagree & 4 & Agree & & & \\
\hline
\end{tabular}


Table 5. Relationship analysis between factor 1 and factor 2

\begin{tabular}{|l|l|}
\hline Correlation Coefficient $=\mathrm{r}$ & \multicolumn{1}{|c|}{0.62} \\
\hline $\mathrm{N}=150, p<0.05$ & \multicolumn{1}{|l|}{$\begin{array}{l}\text { There is a significantly high/strong positive relationship between Task Oriented Roles } \\
\text { Summary: }\end{array}$} \\
\hline
\end{tabular}

Table 6. Relationship analysis between factor 1 and factor 3

\begin{tabular}{|l|l|}
\hline Correlation Coefficient $=\mathrm{r}$ & 0.24 \\
\hline $\mathrm{N}=150, p<0.05$ & $\begin{array}{l}\text { There is a significantly low/weak positive relationship between Task Oriented Roles } \\
\text { Factor and Self Oriented Roles Factor }\end{array}$ \\
\hline Summary: & Fact \\
\hline
\end{tabular}

Table 7. Relationship analysis between factor 2 and factor 3

\begin{tabular}{|l|l|}
\hline Correlation Coefficient $=\mathrm{r}$ & \multicolumn{1}{|c|}{0.21} \\
\hline $\mathrm{N}=150, p<0.05$ & $\begin{array}{l}\text { There is a significantly low/weak positive relationship between Relationship Oriented } \\
\text { Roles Factor and Self Oriented Roles Factor }\end{array}$ \\
\hline Summary:
\end{tabular}

Table 8. Correlations across all factors of team building in UKM

\begin{tabular}{|c|c|c|c|c|}
\hline Pearson Correlation & Factor 1 & Factor 2 & Factor 3 & Sig. (2-tailed) \\
\hline Factor 1 & 1.000 & 0.620 & 0.240 & $0.000^{*}$ \\
\hline Factor 2 & 0.620 & 1.000 & 0.210 & $0.000^{*}$ \\
\hline Factor 3 & 0.240 & 0.210 & 1.000 & $0.000^{*}$ \\
\hline $\mathrm{N}=150, p<0.05$ &
\end{tabular}

